\title{
THE STUDY OF DEPOPULATED HISTORICAL ENSEMBLES IN THE PROVINCE OF TERUEL: A TOOL TO MAP, PROTECT AND CONSERVE THEIR VERNACULAR HERITAGE AND IDENTITY
}

\author{
C. Villalba Montaner ${ }^{1, *}$ \\ ${ }^{1}$ Sección de Patrimonio Cultural, Servicio Provincial de Educación, Cultura y Deporte de Teruel, Departamento de Educación, \\ Cultura y Deporte, Gobierno de Aragón, C/ San Vicente de Paúl, 3, Teruel, 44002 - cvillalbam@aragon.es
}

\author{
Commission II - WG II/8
}

KEY WORDS: Historic ensembles, Rural heritage, Depopulation, Inventory, Vernacular heritage, Urban planning

\begin{abstract}
:
There are 23 rural historical ensembles listed as BIC in the province of Teruel, one of the most depopulated areas in Spain. On the one hand, the lack of economic and demographic pressure in this region has made it possible to preserve many of the typological features of their vernacular architecture. On the other hand, the loss of permanent inhabitants and skilled craftsmanship practitioners has led to a worrying lack of maintenance and abandonment, which threatens their future conservation. The Cultural Heritage Department (Gobierno de Aragón) has been promoting several studies aimed at the protection of 6 different listed case-studies (Albalate del Arzobispo, Calaceite, Rubielos de Mora, Mirambel, Beceite and Teruel). Despite being very small, municipalities are the only competent bodies for the elaboration of the Special Protection master plans of each HE, according to Urban Planning and Cultural Heritage legislation. Hence, the primary purpose of these studies is to support them by analysing their heritage significance and singularities so they can use them as the base for master plans. They will also help raise awareness of their cultural values among local communities, while avoiding the mere conservation of empty urban and rural landscapes. The methodology comprises the identification, analysis and diagnosis of the heritage values that build their identity, thanks to a thorough inventory of all the vernacular constructive techniques, components and zones with a distinguishable character within the urban tissue and its environment.
\end{abstract}

\section{INTRODUCTION}

\subsection{Context}

The province of Teruel is one of the three provinces in Aragón, a region located in the North-East of Spain.

Like other countries, Spain has an irregular demographic distribution, since most of its population is concentrated both on the coastline and the capital, Madrid. Because of that, most inland areas suffer from particularly low population density, and the zone of Teruel is no exception. Despite its size, $18,810 \mathrm{~km} 2$, the exodus to urban centres, together with the negative natural growth, has led to an inevitable demographic desertification. In fact, only 134,137 inhabitants (INE, 2019), which makes an average population density of only 7.13 inhabitants $/ \mathrm{km}^{2}$.

According to a report by the Centre for Studies on Depopulation and Development of Rural Areas, CEDDAR (Pinilla et al., 2017), this situation is a symptom of serious structural problems that make policy-making very crucial at this stage. The worrying lack of economic and social dynamism in rural areas has made it possible to preserve its vernacular architecture from major modifications or even demolishment.

\subsection{Legislative framework}

The highest protection for any heritage site is defined by both the national and the Aragonese Cultural Heritage legislation as 'BIC' ('bien de interés cultural'-listed site of cultural interest) and includes two different categories, namely 'monuments' and

\footnotetext{
* Corresponding author

1 Law 16/1985, 25th June, of Spanish Historic Heritage (LPHE),
}

'ensembles of cultural interest'. The latter also comprises several kinds of sites, such as historic ensemble, historic garden, historic site, palaeontological site, archaeological site and site of ethnographic interest (Ley 16/1985, de 25 de junio, del Patrimonio Histórico Español; Ley 3/1999, de 10 de marzo, del Patrimonio Cultural Aragonés) ${ }^{1}$.

Remarkably, there are 24 listed historic ensembles in the province of Teruel (hereafter, HE), and no less than 23 of them belong to rural, depopulated areas.

Once a HE is listed, the municipality must follow article 41 of the LPCA by approving an urban plan ('Special Plan of Protection') to guarantee the compatibility of the conservation of its exceptional cultural heritage with other urban aspects, such as land use or energy efficiency. However, some small municipalities have very few technical and budgetary resources and, therefore, find it difficult to observe all these requirements. Besides, it might even lead to conflicts among their few inhabitants.

As a result, only 1 out of the 23 listed HEs of Teruel, Albarracín, has approved a 'Special Plan for the Protection of the HE' up to date. Since Cultural Heritage falls within the competency of the regional governments in Spain, the Directorate General of Cultural Heritage (Gobierno de Aragón) started an initiative in 2016 to support these small towns by elaborating exhaustive studies of several HEs. These studies are to become an essential part of the future municipal Special Plans of Protection of the historic ensembles.

Law 3/1999, $10^{\text {th }}$ March, of Aragonese Cultural Heritage (LPCA) Please note that the cited legislation is only available in Spanish. (See 'References'). 


\begin{tabular}{|l|c|c|c|}
\hline \multicolumn{1}{|c|}{ Listed HE } & Inscription & Character & Special Plan \\
\hline Albalate del Arzobispo & 1982 & Rural & \\
Albarracín & 1961 & Rural & X \\
Beceite & 2007 & Rural & \\
Calaceite & 2007 & Rural & \\
Camino de los Pilones & 2008 & Rural & \\
Cantavieja & 1981 & Rural & \\
Castellote & 2007 & Rural & \\
Cuevas de Cañart & 2004 & Rural & \\
Jabaloyas & 2012 & Rural & \\
La Fresneda & 1983 & Rural & \\
La Iglesuela del Cid & 1983 & Rural & \\
Linares de Mora & 2004 & Rural & \\
Mirambel & 1980 & Rural & \\
Miravete de la Sierra & 2007 & Rural & \\
Mora de Rubielos & 2004 & Rural & \\
Mosqueruela & 1982 & Rural & \\
Orihuela del Tremedal & 1972 & Rural & \\
Puertomingalvo & 2007 & Rural & \\
Ráfales & 1983 & Rural & \\
Rubielos de Mora & 2007 & Rural & \\
Teruel & 2010 & Urban & in progress \\
Tronchón & 2007 & Rural & \\
Valderrobres & 2004 & Rural & \\
Villarroya de los Pinares & 1982 & Rural & \\
\hline
\end{tabular}

Table 1. Listed Historic Ensembles in Teruel

During the 2016-2019 triennium, the studies of the rural ensembles of Albalate del Arzobispo, Beceite, Calaceite, Mirambel and Rubielos de Mora were carried out. Likewise, the 20th-century garden city in the HE of Teruel was the object of another study in 2018 .

\section{THE STUDIES FOR THE PROTECTION OF LISTED HISTORIC ENSEMBLES}

\subsection{Aims and scope of the studies}

The main goal of these studies is to make inventories and determine their singularities, so they can become the base of comprehensive Special Plans, focused on their sustainable urban planning, and the conservation and protection of their heritage values. Therefore, they must comply with all urban planning and cultural heritage legal requirements.

A Special Plan aims to ensure the protection of the heritage ensemble (D.L. 1/2014, de 8 de julio, Texto Refundido de la Ley de Urbanismo de Aragón) ${ }^{2}$. It has to identify and analyse all types of interventions, the state of conservation of its buildings and urban tissue, and the use that might be compatible with the preservation of their heritage values. Then, it has to include a thorough inventory and bylaws for the subsequent Plan, too.

Historic ensembles are a very fragile sum of harmonic and distinguishable parts (buildings, public spaces, architectural features, rural and urban landscapes, etc.). They can transform as a whole when a single element or detail is inappropriate or stands out improperly.

2 Legislative Decree 1/2014, 8th July, Consolidated Text of the Law of Urban Planning in Aragón.
Not only are the studies based on the aforementioned legal regulations but also they follow the guidelines of some widely recognised documents at a national and an international level, such as the 'National Plan for Traditional Architecture' (IPCE, 2015) or the ICOMOS Charter on the built vernacular heritage (ICOMOS, 1999). Thus, the specific objectives of the studies are:

- To produce knowledge and accurate data by carrying out some detailed historical and archaeological research;

- The analysis of the integration of the HE within potential growth areas;

- The identification and protection of cultural, architectural, historical and landscape values, etc., which belong to the different layers of the HE. They make up its identity through a rigorous inventory and identification of vernacular construction techniques, typologies, and distinguishable units (neighbourhoods) within the urban and peri-urban tissue (implantation within the environment, borders, etc.);

- The conditions and regulations to be met by any new constructions or interventions within the historic ensemble.

- The survey of the road network to solve traffic conflicts and ensure as much accessibility as possible, without compromising the heritage values that have been identified and must be preserved as a priority;

- The improvement and enhancement of both anthropised unbuilt spaces (streets, squares, parks, etcetera) and landscape by considering paving, street furniture, lighting and infrastructures;

- The investigation of the potential of residential use and other complementary uses to revitalise the area, by safeguarding its urban, architectural and social components and intangible heritage (collective identity feeling, living traditions, craftsmanship, etc.);

- The need to consider the urban tissue of the HE as a whole, by avoiding the assessment of the individual monumental buildings only;

- To avoid facadism, the mere preservation of a set of empty urban landscapes, and other actions that can distort the traditional and vernacular elements of the municipality;

- The involvement of local communities and the participation of as many stakeholders as possible.

\subsection{Methodology}

The study must follow four phases, to be carried out by a multidisciplinary team:

1. Research phase: Source research (including archive research and interviews and visits to buildings with owners, etc.) and an in-depth analysis of the features of the HE.

2. Diagnosis phase: interpretation of the outcome of the first phase.

3. Synthesis phase: development of the main guidelines and proposals of the study itself, which will be the base of a future Special Plan for the Protection of the HE.

4. Presentation of the results to the local government and local communities. 


\subsection{Structure and content of the studies}

In order to provide the municipalities with a document they can successfully shape into a forthcoming and binding Special Plan for Protection of the HE, the proposed framework for the studies replicates the general structure of urban plans (D.L. 1/2014, de 8 de julio, Texto Refundido de la Ley de Urbanismo de Aragón) ${ }^{2}$. So, each study must comprise the Statement, Plans, (Draft) Regulations and Inventory. From the cultural heritage protection point of view, it may include, but is not limited to, the following sections:

\subsubsection{Statement/Report}

- Introduction and scope of the study;

- Current urban plans and global interventions related to the HE;

- Analysis of the HE:

- Historical analysis;

- Analysis of the evolution of its morphology;

- Analysis of the current building conditions (volume, plot size, regulatory height, current conditions of intervention); especially in the buffer zones of monuments, highlighting the deficiencies of the urban planning at these critical points;

- Analysis of the traffic and the road network (including pedestrian itineraries), infrastructures and plots where it would be possible to design dissuasive car parks;

- Analysis of buildings and urban spaces (typologies, squares, streets, dead-ends, alleys, parks, vacant areas, etc.);

- Analysis of vernacular construction techniques, materials, details. It may include the physicochemical analysis of traditional mortars, renderings, stones, etc.

- Landscape analysis: characterisation of the cultural landscapes, relationships with the environment, builtunbuilt, visual itineraries, etc.;

- Chromatic analysis of the municipality and its surroundings. Elaboration of a colour chart for reference;

- Analysis of the values to preserve (cultural, architectural, landscape, historical, intangible, natural, etc.).

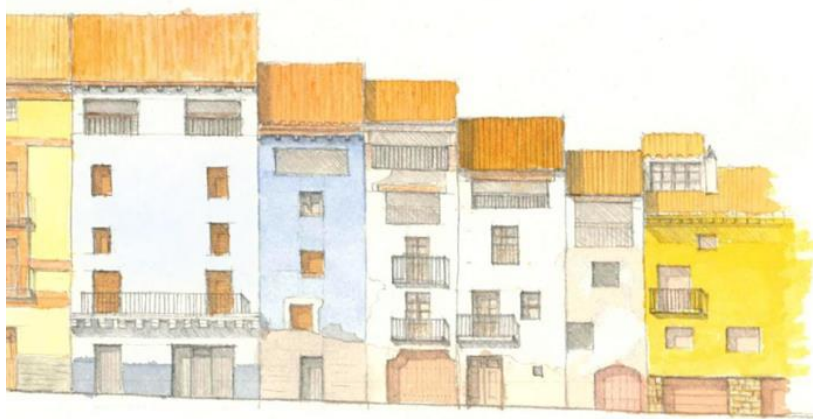

Figure 1. Typology and chromatic analysis of Calle Baja street, in Albalate del Arzobispo

(Gil Bordás, 2016).
- Diagnosis:

- Interpretation and conclusions of the analysis;

- SWOT analysis (strengths-weaknesses-opportunitiesthreats).

- Aims and criteria of the proposals;

- Description and justification of the specific proposals, taking into account the following aspects:

- Planning of the HE;

- Protection measures and criteria to adopt;

- Proposals to improve the HE;

- Identification of improper buildings, elements and spaces within the HE.

- References.

\subsubsection{Plans}

The maps and plans shall adopt the most suitable scale to each map or graphic analysis in the study. Also, to facilitate their inclusion within the 'Special Plan', they will be the subject of some urban planning normalisation guidelines, as set by the regional regulations (Decreto 78/2017, de 23 de mayo, Norma Técnica de Planeamiento) ${ }^{3}$ :

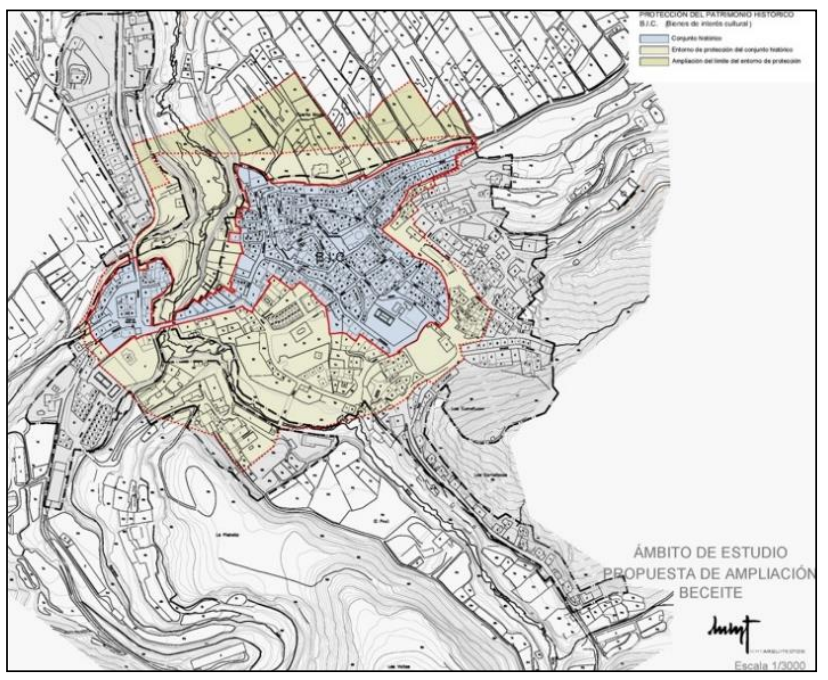

Figure 2. The Study of Beceite proposed an extension of its buffer zone (in brown) to the north

(Murría, 2018).

- Information Plans.

- Location map and scope of the study; BIC Historic Ensemble and its buffer zone;

- Listed buildings and areas of interest: BIC, other buildings of interest according to architectural value, etc., areas with urban or archaeological values, etc. All these must be part of the inventory;

- Historical evolution;

- Current layout;

- Built space (plots);

- Defined areas, morphological units / neighbourhoods;

3 Decree 78/2017, 23rd May, Urban Planning Technical Norm (NOTEPA). 
- Detailed land uses;

- Heights of the built tissue;

- Building typologies;

- Public spaces;

- Nested road network in relation to the entire municipality;

- Characterisation of the unbuilt spaces: public and private;

- Paving (identify traditional examples, recent ones, patterns, materials, integration of infrastructures...);

- Infrastructures: electricity, lighting (overhead wires and/or underground network), water supply, sewage network, telecommunications;

- State of conservation of public space, buildings and infrastructures, identifying potential ruins (according to law).

- Proposals

- Delimitation of the listed HE and its buffer zone, and reasoned proposal for its modification, if appropriate.

- Protection plans;

- Identification of morphological units or neighbourhoods;

- Public spaces and vacant areas. Guidelines for future interventions and design;

- Road network (including car parks);

- Priority areas (definition of most deteriorated areas);

- Infrastructures, prioritising underground works for overhead wiring to avoid visual pollution.

\subsubsection{Proposed/Draft Regulations}

At this stage, the study may formulate some draft regulations, but they will only become binding once they are included in the Special Plan (D.L. 1/2014, de 8 de julio, Texto Refundido de la Ley de Urbanismo de Aragón) ${ }^{2}$.

- Guidelines and terminology, which should follow national or international charters (e.g. Burra Charter), for reference.

- Existing buildings:

- Definition of the level or category of protection based on the inventory;

- Types of interventions possible (must be compatible with its category of protection):

- Conservation or 'minimal intervention';

- Maintenance;

- Consolidation;

- Restoration;

- Refurbishment;

- Retrofit;

- Renovation;

- Adaptation;

- Reconstruction.

- Annex: It shall include an inventory to elaborate on the identification of traditional typologies and constructive techniques. It may include, but is not limited to: construction techniques, roofing systems, facades, windows, doors, eaves, paving, renderings, etc.

Besides, it is advisable to plan some specific draft regulations to apply to each of the identified morphological units (blocks, neighbourhoods, streets, squares, etc.).

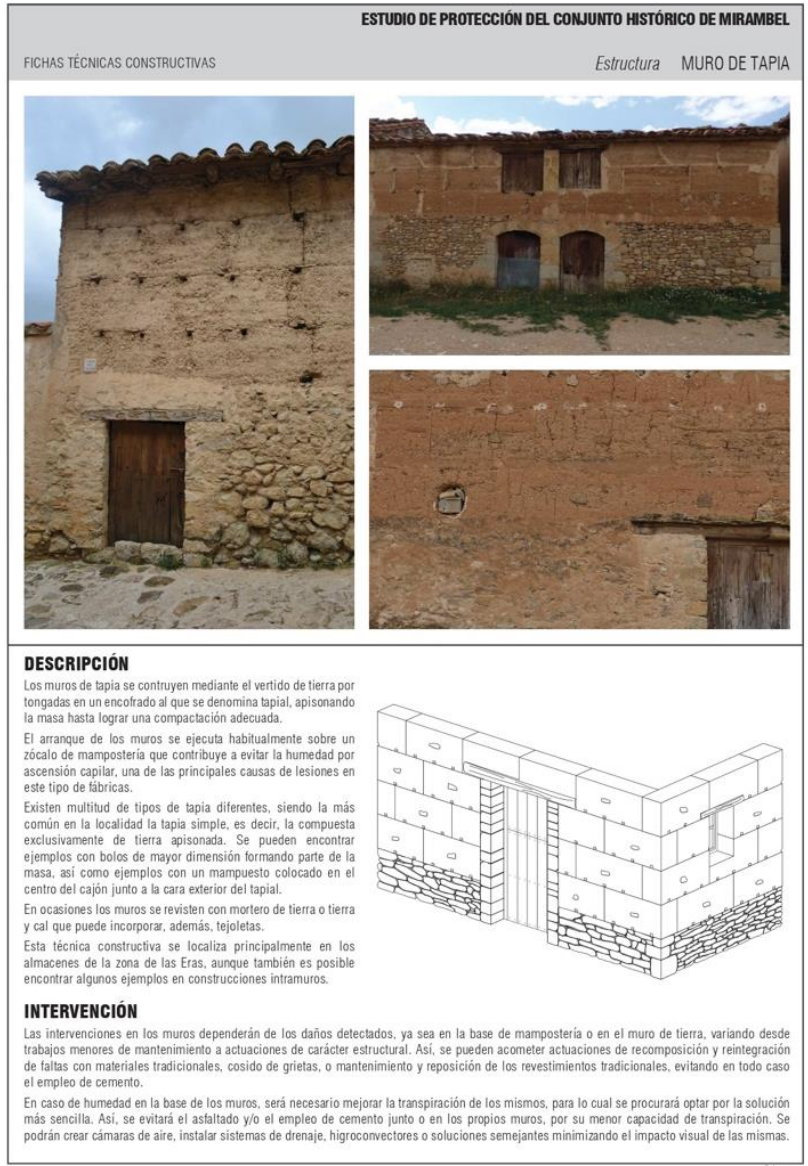

Figure 3. Extract of the typology inventory. Construction techniques: rammed earth walls in Mirambel

(Vegas et al., 2018).

- Design guidelines for new buildings:

- Harmonization with the historic urban landscape;

- Facades (maximum dimensions -height, depth, width-, proportions and composition -openings, materials, etc.);

- Details: Joinery, railings, blinds...

- Rooftops.

The need to harmonise with the traditional features identified in the typologies inventory is essential. Foreign elements and false imitations of materials and techniques shall not be allowed. Exceptional contemporary buildings might be possible, as long as they contribute to the ensemble's historic urban landscape and thus be passed by the Provincial Commission of Cultural Heritage.

- Plot regulations. Subdivision of historical plots is to be prohibited.

- Regulations for ruins, for buildings which do not comply with the current urban plan and for improper constructions.

- Regulations for interventions in undeveloped land, e.g. straw lofts and plots, dissuasive car parks, etc.

- Protection of urban and cultural landscapes:

- Regulations to avoid visual pollution (signage, overhead wires, aerials, etc.)

- Plot delimitation: fences, visual relationships, etc.

- Unbuilt surroundings of the historic ensemble.

- Protection of archaeological and palaeontological heritage. 


\subsubsection{Inventory}

This section needs to reflect the most remarkable buildings and spaces in the HE and their most significant features. Then, a level or category of protection must be assigned to each of them. The content must include general data of the building or site, its protection category (I, II, III), an extensive description, a location map, details about its use, state of conservation, the interventions allowed for this category of protection, photos, etc.

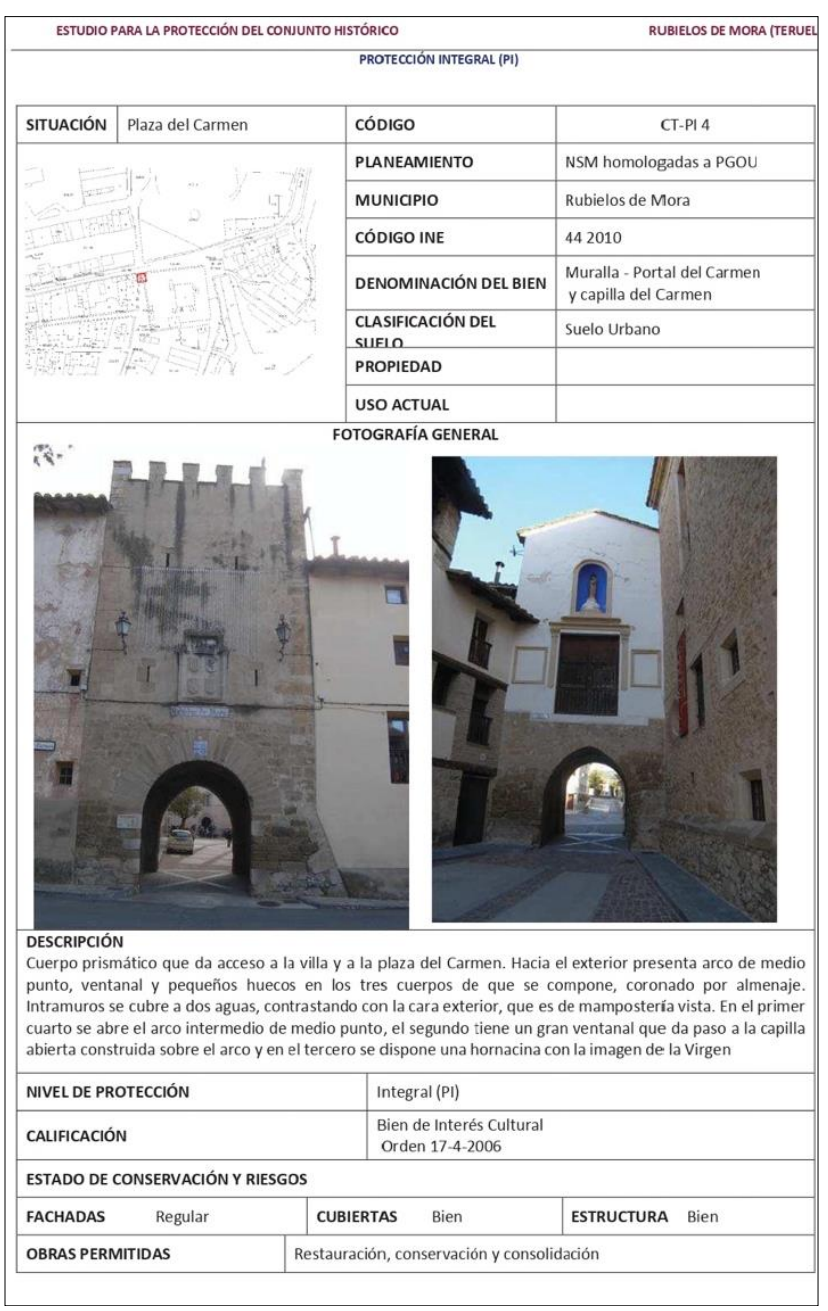

Figure 4. Inventory card. Remains of the medieval town walls of Rubielos de Mora (Sanz Zaragoza, 2017).

\subsection{Results}

The six studies shed light on the fragile situation of cultural heritage in small towns.

The teams (architects, historians, urban planners) identified some aspects that affect $100 \%$ of the case-studies:

- The practitioners' lack of training in vernacular heritage leads to foreign construction techniques and physicochemical incompatibilities between materials;

Since there are no bad intentions behind these interventions, the outcome of the studies should foster some awarenessraise campaigns and workshops, to involve all the stakeholders (owners, local governments, architects, builders, etc.);

- Remote rural areas suffer from lesser infrastructures than cities. If there is any progress, heritage values may not be a priority;

- Owners find too many disadvantages and restrictions because of living in a listed HE;

- Depopulation is a major issue in rural areas. People prefer to live in larger towns, and only some spend time in the village over the weekends and holidays. As a result, ruins and lack of maintenance threaten their integrity;

- Small changes could make a difference. The cooperation between stakeholders may diminish inadequate interventions and make them more sustainable. The outcome would be visible soon, and it would help build a stronger sense of belonging to a certain area;

- Additional measures are necessary to guarantee the survival of HE. The adoption of respectful urban regeneration plans and the collaboration between public organisms to provide the local governments with comprehensive technical support is vital.

\section{CONCLUSIONS}

The initiative presented in this paper shows a scheme and set of actions to support the municipalities that manage listed HE in the process of development of the so-called 'Special Plans for the protection of historic ensembles' and to raise awareness among both policy-makers and local communities.

These case studies have built knowledge about the richness of cultural heritage and will help the discourse in areas where depopulation is a structural problem. Sometimes, their inhabitants do not know or even appreciate their vernacular heritage and seek foreign or picturesque solutions. Thus, it is common that spontaneous interventions end up damaging the HE values for good.

Engaging local communities, authorities, heritage and craftsmanship practitioners and other stakeholders is necessary for these studies and plans to succeed. In forthcoming studies, community involvement will continue to be the key to encourage local governments to take up the task of approving their Special Plans.

Actually, this could be the starting point of a creative impulse of social and economic measures and opportunities in times of crisis and scarce resources. The aim is to ensure living, sustainable towns where cultural heritage and its conservation may become an asset to fight against the challenge of the depopulation of remote rural areas.

\section{ACKNOWLEDGEMENTS}

The Studies for protecting Historic Ensembles of the province of Teruel have been promoted and financed by the Prevention and Protection of Cultural Heritage Office of the Directorate General of Cultural Heritage (Gobierno de Aragón), since 2016. 
They result from the joint effort of its technical team, who coordinated and supervised all the studies, and the thorough work of each multidisciplinary team that developed the studies themselves. Thus, special thanks to the teams led by José A. Gil (Albalate del Arzobispo and Calaceite), José M ${ }^{a}$ Sanz (Rubielos de Mora), Fernando Vegas \& Camilla Mileto - Universidad Politècnica de València (Mirambel), José Fernando Murría MMT Arquitectos (Beceite) and Miguel Sancho (Teruel).

Finally, thank you to the local governments for their support and also to the people from the villages who have actively collaborated in the studies by opening their homes to the working teams. They have also provided precious oral information about their heritage and the problems they face because of living in a listed depopulated town.

\section{REFERENCES}

Aragón. D.L. 1/2014, de 8 de Julio, Texto Refundido de la Ley de Urbanismo de Aragón (TRLUA), Boletín Oficial de Aragón, 18 de julio 2014, no. 140.

https://www.boe.es/buscar/pdf/2014/BOA-d-2014-90410-

consolidado.pdf ( $31^{\text {st }}$ March 2020)(Only available in Spanish).

Aragón. Decreto 78/2017, de 23 de mayo, Norma Técnica de Planeamiento (NOTEPA), Boletín Oficial de Aragón, 2nd June, 2017, no. 104.

http://www.boa.aragon.es/cgi-

bin/EBOA/BRSCGI?CMD=VEROBJ\&MLKOB=96497186232

$3 \&$ type $=$ pdf $\left(31^{\text {st }}\right.$ March 2020) (Only available in Spanish).

España. Ley 16/1985, de 25 de junio, de Patrimonio Histórico Español (LPHE), Boletín Oficial del Estado, 29 de Junio, 1985, no. 155

https://www.boe.es/buscar/act.php?id=BOE-A-1985-12534

(31 ${ }^{\text {st }}$ March 2020) (Only available in Spanish).

España. Ley 3/1999, de 10 de marzo, de Patrimonio Cultural Aragonés (LPCA), Boletín Oficial de Aragón, 29 de marzo, 1999, no. 36 .

https://www.boe.es/buscar/pdf/1999/BOE-A-1999-8270consolidado.pdf (31 ${ }^{\text {st }}$ March 2020) (Only available in Spanish).

ICOMOS, 1999: Charter on the built vernacular heritage. https://www.icomos.org/images/DOCUMENTS/Charters/verna cular_e.pdf (30th January 2020).

INE (Instituto Nacional de Estadística), 2019: Cifras oficiales de población resultantes de la revisión del Padrón municipal de enero, 2019. https://www.ine.es/jaxiT3/Tabla.htm?t=2899\&L=0 (30 $0^{\text {th }}$ January 2020$)$.

IPCE (Instituto del Patrimonio Cultural de España), 2015: Plan Nacional de Arquitectura Tradicional.

https://sede.educacion.gob.es/publiventa/descarga.action?f_codi go_agc $=15101 \mathrm{C}$ (30th January 2020).

Pinilla, V., Sáez, L.A.2017: La despoblación rural en España: génesis de un problema y políticas innovadoras. Informes CEDDAR. Centro de Estudios sobre la Despoblación y Desarrollo de Áreas Rurales, 2017-2, 3-16.

Studies for the Protection of Historic Ensembles in the province of Teruel, promoted, coordinated and supervised by Gobierno de Aragón (unpublished):
Gil Bordás, J.A., 2016: Estudio para la protección del Conjunto Histórico de Albalate del Arzobispo (Teruel).

Sanz Zaragoza, J.M., 2017: Estudio para la protección del Conjunto Histórico de Rubielos de Mora (Teruel).

Murría, J.F., Murría, V., Murría, J.J, Becerra, J., 2018: Estudio para la protección del Conjunto Histórico de Beceite (Teruel).

Vegas, F., Mileto, C., 2018: Estudio para la protección del Conjunto Histórico de Mirambel (Teruel). 